\title{
Gastrointestinal Stromal Tumor pT4 TNM
} Finding v8

National Cancer Institute

\section{Source}

National Cancer Institute. Gastrointestinal Stromal Tumor pT 4 TNM Finding v8. NCI

Thesaurus. Code C136763.

Gastrointestinal stromal tumor measuring more than $10 \mathrm{~cm}$ in greatest dimension. (from AJCC 8th Ed.) 